\title{
Analisis Pembelajaran Matematika Materi Bangun Ruang Kubus dan Balok dengan Menggunakan Model Konstruktivisme Berbasis Lingkungan
}

\author{
Abdillah Halimi $^{1 *}$, Wijonarko², Ferina Agustini ${ }^{3}$ iD \\ 1,2,3 Program Studi Pendidikan Guru Sekolah Dasar, Universitas PGRI Semarang, Indonesia \\ *Corresponding author: halimi898@gmail.com
}

\section{Abstrak}

Penelitian ini dilatarbelakangi oleh nilai siswa dalam pembelajaran matematika materi bangun ruang kubus dan balok serta minat siswa terhadap pelajaran matematika. Penelitian ini bertujuan untuk menganalisis model kontruktivisme berbasis lingkungan dalam pembelajaran matematika materi bangun ruang kubus dan balok di sekolah dasar. Desain penelitian ini adalah desain penelitian deskriptif kuantitatif yang diarahkan untuk menganalisis penerapan model pembelajaran konstruktivisme berbasis lingkungan yang dilakukan oleh guru dalam mata pelajaran matematika. Metode wawancara, observasi, dan dokumentasi merupakan teknik pengumpulan data yang digunakan oleh peneliti. Validasi data menggunakan triangulasi sumber dan teknik. Sedangkan Teknik analisis data yaitu dengan pengumpulan, reduksi, penyajian, dan penarikan kesimpulan data. Hasil penelitian menunjukkan bahwa terjadi kenaikan yang lumayan baik dari 10 siswa yang nilainya baik menjadi 18 siswa yang memiliki nilai baik sehingga jika di buat persentase adalah 78,3\% untuk siswa yang nilailnya baik dan $21,7 \%$ anak nilainya kurang baik atau tidak bisa memenuhi KKM. Berdasarkan hasil penelitian tersebut dapat disimpulkan bahwa penggunaan model pembelajaran kontruktivisme berbasis lingkungan dapat mempengaruhi hasil belajar siswa dengan baik.

Kata kunci: Model Pembelajaran Kontruktivisme, Lingkungan.

\section{Abstract}

This research is motivated by the students' scores in learning mathematics on the subject of cube and block shapes and students' interest in mathematics. This study aims to analyze the model of environmental-based constructivism in mathematics learning materials for building blocks and cubes in elementary schools. The design of this research is a quantitative descriptive research design that is directed to analyze the application of the environmental-based constructivism learning model conducted by teachers in mathematics. Interview, observation, and documentation methods are data collection techniques used by researchers. Validation of data using triangulation of sources and techniques. While the data analysis technique is by collecting, reducing, presenting, and drawing conclusions of data. The results showed that there was a fairly good increase from 10 students who scored well to 18 students who had good grades so that if the percentage was made, it was 78,3\% for students with good grades and 21,7\% for children whose grades were not good or not. can meet the KKM. Based on the results of these studies, it can be concluded that the use of environmental-based constructivism learning models can influence student learning outcomes well.

\section{INTRODUCTION}

Mata pelajaran matematika perlu diberikan kepada semua peserta didik mulai dari sekolah dasar untuk membekali peserta didik dengan kemampuan berpikir logis, analitis, sistematis, kritis, dan kreatif, serta kemampuan bekerja sama (Dipayana et al., 2019; Harianti, 2018; Setyadi \& Qohar, 2017; Sudarma, 2018). Untuk mengembangkan kemampuan tersebut, pendidikan harus mengarahkan siswa kepada penggunaan berbagai situasi dan kesempatan untuk menemukan kembali matematika dengan cara mereka sendiri. Matematika memang berkaitan erat dengan kehidupan dan juga tidak dapat dipungkiri bahwa tidak sedikit konsep-konsep matematika yang erat sekali kaitannya dengan kehidupan sehari-hari, misalnya tentang kesamaan, lebih besar, lebih kecil, penjumlahan, pengukuran dan sebagainya sehingga pembelajaran yang inovatif diperlukan dalam pengajaran matematika

$\begin{array}{lll}\text { History: } & & \text { Publisher: Undiksha Press } \\ \text { Received } & : 11 \text { November } 2020 & \text { Licensed: This work is licensed under } \\ \text { Revised } & : 12 \text { November } 2020 & \text { a Creative Commons Attribution 3.0 License } \\ \text { Accepted } & : 20 \text { Desember } 2020 & \text { CC } \\ \text { Published } & : 25 \text { Mei } 2021 & \text { (C) }\end{array}$


untuk membantu siswa dalam penerimaan materi pembelajaran (Azhari \& Irfan, 2018; Jannah et al., 2019; Juniarti et al., 2020; Rivaldi et al., 2018).

Berdasarkan hasil observasi dan wawancara di SDN Lamper Tengah di kota Semarang dan pada SDN Karangsari 03 di kota Demak ditemukan permasalahan mengenai minat dan mengenai masalah terhadap pelajaran matematika kelas tinggi pada kelas $\mathrm{V}$ yaitu menurunya hasil belajar siswa terhadap nilai matematika. Hal ini terjadi dikarenakan banyak faktor antara lain terjadi karena minat dan motivasi siswa yang kurang akan pelajaran matematika, siswa lebih suka bermain dengan temannya dibandingkan menerima pelajaran dari guru di kelas, hal ini terjadi karena kurangnya pemahaman siswa mengenai soal-soal pelajaran matematika yang identik dengan rumus-rumus dan juga angka-angka padahal jika dikaji lagi matematika bukanlah hal yang sulit dikarenakan siswa mengalami kegiatan matematika pada kehidupan sehari-hari.

Permasalahan tersebut jika dibiarkan akan berdampak buruk pada proses dan hasil pembelajaran di sekolah tersbeut. Maka diperlukan sebuah solusi untuk permaslahan tersebut. Salah satu solusi tersebut adalah dengan menerapkan model pembelajaran yang inovatif dan kreatif sehingga pembelajaran dapat menarik minat siswa. Salah satu model pembelajaran yang dapat diterapkan adalah model pembelajaran kontruktivisme. Model pembelajaran konstruktivisme adalah model pembelajaran dengan menempatkan siswa sebagai agen aktif dalam proses belajar bermakna. Siswa tidak hanya menerima materi tapi juga menginterpretasikan materi. Penggunaan model konstruktivisme ini membuat siswa dituntut aktif, sedangkan guru bertindak sebagai fasilitator. Dengan demikian, ada perubahan paradigma dalam pembelajaran, guru aktif dan siswa pasif menjadi siswa aktif belajar dan guru sebagai fasilitator. Dalam penerapannya, model ini akan dipadukan dengan lingkungan.

Saat ini, sangat diperlukan pendekatan pembelajaran yang sesuai dengan tahap perkembangan intelektual siswa dan dapat memberikan makna bagi siswa. Pembelajaran tidaklah selalu harus dilakukan di dalam kelas, terkadang pembelajaran juga bisa dilakukan di luar kelas, di lingkungan sekitar, dan di alam terbuka (Hasanah et al., 2016; Primayana et al., 2019). Pembelajaran di luar kelas ataupun di lingkungan sekitar memungkinkan siswa untuk mengalami langsung konsep yang dipelajari dan dapat mengembangkan penalaran logis siswa (Primayana et al., 2019; Purwaningtyas et al., 2017; Wahyudin, 2018). Hal ini dikarenakan materi pembelajaran dirangkum menjadi kegiatan-kegiatan yang dekat dengan pengalaman siswa dalam kesehariannya sehingga menjadi bermakna. Belum banyak kajian mendalam mengenai model konstruktivisme berbasis lingkungan pada pembelajaran matematika di tingkat sekolah dasar.

Beberapa penelitian yang relevan dengan penelitian ini seperti penelitian yang dilakukan oleh (Sujarwanto, 2016) menemukan bahwa proses pembelajaran dengan menerapkan model pembelajaran Konstruktivisme dapat meningkatkan aktivitas belajar siswa pada materi ciri-ciri mahluk hidup di kelas III. Kemudian penelitian yang dilakukan oleh (Primayana et al., 2019) menemukan bahwa terdapat perbedaan pada hasil belajar IPA siswa yang mengikuti pembelajaran model pembelajaran kontekstual berbasis lingkungan dengan siswa yang mengikuti pembelajaran konvensional. Penelitian lain juga menemukan bahwa model pembelajaran konstruktivisme cocok diterapkan dalam pembelajaran matematika teknik (Azman et al., 2020). Tujuan penelitian ini menganalisis penggunaan model kontruktivisme berbasis lingkungan dalam pembelajaran matematika materi bangun ruang kubus dan balok di sekolah dasar.

\section{MATERIALS AND METHODS}

Desain penelitian ini adalah desain penelitian deskriptif kuantitatif yang diarahkan untuk menganalisis penerapan model pembelajaran konstruktivisme berbasis lingkungan 
yang dilakukan oleh guru dalam mata pelajaran matematika. Metode wawancara, observasi, dan dokumentasi merupakan teknik pengumpulan data yang digunakan oleh peneliti. Validasi data menggunakan triangulasi sumber dan teknik. Sedangkan Teknik analisis data yaitu dengan pengumpulan, reduksi, penyajian, dan penarikan kesimpulan data.

\section{RESULTS AND DISCUSSION}

Dalam pembahasan ini akan disajikan pembahasan dari hasil angket siswa mengenai pembelajaran matematika yang selama ini dilakukan dengan guru mata pelajaran matematika. Terdapat 20 soal dan responden sebanyak 23 siswa. Berdasarkan angket yang telah di isi oleh siswa rata-rata siswa menyukai matematika yaitu ada $58 \%$ anak yang menyatakan suka dan $23 \%$ orang anak yang kurang menyukai matematika serta ada $23 \%$ anak yang tidak suka terhadap matematika. Sebagaimana tertera dalam hasil angket no 1 ntuk para siswa yang menyukai mata pelajaran matematika terutama pada materi bangun ruang kubus dan balok hanya terdapat $18 \%$ anak saja, karena rata-rata anak tidak suka menghafal rumus dan merasa kesulitan menghafal sehingga yang paling banyak di temukan adalah kadang-kadang suka yaitu dengan jumlah $61 \%$ anak dari 23 anak serta yang tidak suka dengan materi bangun ruang kubus dan balok terdapat $23 \%$ anak sebagaimana terdapat pada hasil angket no 2 dengan pernyatan "saya suka terhadap materi bangun ruang kubus dan balok". Pada angket no 3 dengan pernyataan "saya mampu menghitung bangun ruang kubus dan balok" yaitu pernyataan yang mengacu pada kemampuan kognitif siswa tentang sejauh mana siswa dapat mengerjakan di dapatkan hasil $40 \%$ anak yang mengakui tidak bisa menghiung bangun ruang kubus dan balok, lalu terdapat $40 \%$ orang anak yang masih ragu dengan jawaban kadangkadang terdapat 9 orang anak serta yang mengakui bisa mengerjakan dengan benar soal materi bangun ruang kubus dan balok terdapat $23 \%$ orang saja yang dimana jumlah keseluruhan siswa ada 23 siswa.

Dalam pernyataan siswa terkait motivasi siswa dalam belajar matematika yang menyatakan sering terlambat dalam pembelajaran siswa ada $27 \%$ 0rang dan yang menyatakan tidak pernah terlambat ada $45 \%$ orang serta untuk yang kadang - kadang terlambat ada $31 \%$ siswa masih tergolong banyak yang berminat dalam belajar matematika.untuk pernyataan yang mengacu pada mudahnya mengerjakan matematika ada $53 \%$ orang anak yang menyatakan mudah dan ada $23 \%$ orang yang menyatakan sulit serta ada $27 \%$ orang anak yang menyatakan kadang- kadang mereka kesulitan dalam mengerjakan soal matematika. Dalam sebuah pernyataan yang tujuannya mengetahui sejauh mana siswa memanfaatkan lingkungan sekitar atau berbasis lingkungan siswa menyatakan yang selalu memanfaatkan lingkungan sekitar terdapat $36 \%$ orang anak sedangkan yang tidak pernah memanfaatkan lingkungan sekitar untuk belajar ada $23 \%$ orang anak, untuk anak yang kadang-kadang terdapat $45 \%$ orang anak. Pernyataan yang bertujuan untuk mengetahui siswa bisa mengkonstuksime diri mereka didapatkan hasil yang menyatkan mereka bisa terdapat $40 \%$ orang anak, yang belum bisa mengkonstruksi diri mereka ada 36\% orang anak yang terkadang bisa terdapat $27 \%$ orang anak. Pernyataan yang bertujuan untuk melihat percaya diri siswa dan dapat mengatasi masalah terkait pembelajaran matematika tidak terkecuali materi bangun ruang kubus dan balok didapatkan ada 58\% orang anak yang percaya diri dan dapat menyelesaikan masalah dalam kesulitan pembelajaran matematika untuk yang terkadang bisa dan tidak bisa menyelesaikan kesulitan belajar matematika ada $23 \%$ orang anak.

Dalam pernyataan yang bertujuan agar mengetahui apakah para siswa itu menganggap pembelajaran matematika iu penting bagi mereka tanpa terkecuali materi bangun ruang kubus dan balok ternyata dari 23 siswa terdapat $31 \%$ orang yang menyatakan setuju dan $45 \%$ orang menyatakan tidak serta $27 \%$ orang menyatakan terkadang atau kadang-kadang. Untuk 
pengerjaan secara kelompok dalam mengerjakan matematika di dapatkan $31 \%$ orang yang suka saat mengerjakan secara kelompok dan $50 \%$ orang yang terkadang suka pekerjaan kelompok saat pembelajaran matematika serta $27 \%$ orang tidak suka mengerjakan matematika secara kelompok. Dalam pernyataan no 12 dalam angket yang di berkan pada siswa terdapat $50 \%$ yang suka matematika namun mereka suka melihat dan bertanya jawaban pada temannya, $27 \%$ orang yang tidak suka melakukan hal tersebut dan $31 \%$ orang siswa terkadang melakukan hal itu. Untuk melihat anak yang peduli terhadap nilainya jika kurang baik terutama yang sering mendapatkan nilai yang kurang memuaskan ada $23 \%$ orang anak yang peduli pada nilainya dan terdapat $53 \%$ orang anak yang kurang peduli pada nilainya tersebut serta ada $27 \%$ orang anak yang terkadang peduli terhadap nilai hasil pekerjaan mereka. Untuk melihat tingkat konsentrasi siswa dalam menangkap pembelajaran matematika materi bangun ruang kubus dan balok dengan pernyataan pada angket no 14 di temukan $70 \%$ orang sepakat, $18 \%$ orang tidak setuju dan $13 \%$ orang menyatakan terkadang atau kadang-kadang isi pernyataan tersebut adalah "saya sering terganggu dengan teman saya ketika pembelajaran matematika bangun ruang kubus dan balok sehingga hasil pembelajaran saya kurang memuaskan" bisa dilihat dari itu bahwa tingkat kosentrasi siswa masih kurang karena jika terganggu saat pembelajaran mendapatkan nilai kurang memuaskan.

Pernyataan no 15 yang ditujukan untuk melihat bagaimana tingkat lastic siswa dalam mengerjakan soal bangun ruang kubus dan balok seperti pada angket yaitu seperti berikut ini "saya tidak bertanya pada guru dan teman ketika kesulitan belajar matematika materi bangun ruang kubus dan balok karena tidak bisa mengerjakan soal dan saya ingin mencobanya" ditemukan hasil yaitu $13 \%$ orang memilih jawaban iya atau sepakat pada pernyataan angket, $40 \%$ orang memilih tidak pada pilihan di angket dan $50 \%$ orang menyatakan kadang-kadang seperti pada angket. Dalam melihat penangkapan siswa menerima materi bangun ruang kubus dan balok di berikan pernyataan dalam angket seperti berikut ini " saya dapat mempelajari materi bangunruang kubus dan balok dalam waktu 1 kali pertemuan pembelajaran karena saya semangat dalam menerima materi yang di berikan oleh guru" dengan hasil yaitu 30\% orang menyatan bisa menangkap pembelajaran materi bangun ruang kubus dan balok dalam satu pertemuan, $40 \%$ orang menyatakan tidak bisa menangkap materi bangun ruang kubus dan balok dalam satu pertemuan serta $30 \%$ orang menyatakan kadang - kadang bisa menangkap pembelajaran dalam satu pertemuan dengan mengisi jawaban kadang-kadang pada angket. Pada pernyataan no 17 terkait keseriusan siswa dalam mengikuti pembelajaran matematika terdapat $45 \%$ orang sering mendengarkan guru saat menjelaskan pembelajaran matematika $39 \%$ orang tidak sering mendengarkan guru saat pembelajaran matematika dan $16 \%$ orang kadang - kadang mendengarkan saat pembelajaran matematika.

Pada angket no 18 yang bertujuan untuk melihat apakah siswa sungguh-sungguh dalam pembelajaran matematika $13 \%$ orang menyatakan iya dan sungguh sungguh dalam menerima pembelajaran matematika tak terkecuali materi bangun ruang kubus dan balok, $36 \%$ siswa tidak sungguh-sungguh dalam menerima pembelajaran matematika tak terkecuali materi bangun ruang kubus dan balok, serta 51\% siswa kadang-kadang sungguh-sungguh dalam pembelajaran matematika termasuk materi bangun ruang kubus dan balok. Untuk melihat apakah teman itu berpengaruh dalam kondusif atau terkondisikan tidaknya siswa dalam pembelajaran seperti pernyataan pada angket no 19 dan di dapatkan hasil seperti berikut ini $36 \%$ orang menyatakan sering ngobrol sendiri dan main sendiri saat pembelajaran matematika $35 \%$ orang tidak pernah ngobrol sendiri dengan temannya dan $29 \%$ orang menyatakan kadang-kadang ngobrol sendiri dengan temannya serta main sendiri dengan temannya saat pembelajaran matematika. Pada angket no 20 untuk melihat ketertarikan siswa dalam pembelajaran matematika ternyata di dapatkan $34 \%$ orang siswa tertarik dalam pembelajaran matematika dam $16 \%$ orang tidak tertarik dalam pembelajaran matematika serta ada 50\% anak yang kadang-kadang tertarik dalam pembelajaran matematika. 
Pada nilai pretest ini hasil yang didapatkan siswa kelas V SDN Karangsari 03 Demak yaitu 13 anak atau sebesar 56,5\% siswa yang belum mendapatkan nilai melebihi KKM batas ketuntasan nilai minimal. Kemudian hanya ada 1 anak atau sebesar 4,4\% siswa yang memperoleh nilai sesuai KKM. Sedangkan ada 9 anak atau sebesar 39,1\% siswa yang mendapatkan nilai lebih dari KKM. Pada hasil soal post test atau soal yang di kerjakan sesudah pembelajaran oleh peneliti adalah ada 18 anak atau sebesar 78,3\% peserta didik yang mendapatkan nilai tuntas melebihi KKM antara lain 13 siswa yang nilainya baik melebihi kkm dan 5 siswa yang mendapatkan nilai pas KKM dari data ini saja sudah bisa di lihat terjadi kenaikan yang lumayan baik dari 10 siswa yang nilainya baik menjadi 18 siswa yang memiliki nilai baik sehingga jika di buat persentase adalah 78,3\% untuk siswa yang nilailnya baik dan $21,7 \%$ anak nilainya kurang baik atau tidak bisa memenuhi KKM, namun ada beberapa anak yang nilainya awalnya bagus dan menjadi menurun nilainya itu mungkin di karenakan lupa rumus atau penyebab lainya yang mempengaruhi siswa nilainya menurun. Berdasarkan hasil pretest dan posttest dapat diketahui terjadi peningkatan hasil belajar matematika materi bangun ruang kubus dan balok. Dengan demikian, dapat dikatakan bahwa penggunaan pendekatan kontruktivisme berbasis lingkungan efektif untuk membelajarkan siswa dalam materi bangun ruang kubus dan balok. Berikut adalah diagram peningkatan hasil belajar siswa.

Penerapan model pembelajaran konstruktivisme berbasis lingkungan dapat meningkatkan hasil belajar matematika dikarenakan model pembelajaran ini sesuai dengan teori konstruktivisme yaitu dalam proses pembelajaran peserta didik wajib menekankan dan aktif pada pengembangan pengetahuan mereka, bukan guru. Penekanan aktif ini pada pembelajaran peserta didik harus dikembangkan. Kreativitas serta kegiatan peserta didik akan membantu mereka tetap mampu pada kehidupan kognitif mereka. Pembelajaran dengan model konstruktivisme berbasis lingkungan dapat membantu peserta didik dalam menemukan dan membuat konsep matematika dengan menggunakan kemampuan mereka sendiri lewat proses internalisasi sebagai akibat dari rekonstruksi pengetahuan menggunakan model ini. Pengetahuan barunya itu dibentuk atas dasar pengetahuan sebelumnya.

Kelebihan menggunakan model pembelajaran konstruktivisme yaitu: 1). memberikan kesempatan kepada siswa untuk mengemukakan pendapatnya dengan bahasa sendiri; 2) memberikan kesempatan kepada siswa untuk berpikir tentang pengalamannnya sehingga lebih kreatif dan imajinatif; 3) memberikan kesempatan kepada siswa untuk mencoba gagasan baru; 4) memberi pengalaman yang berhubungan dengan gagasan yang telah dimiliki siswa; 5) mendorong siswa untuk memikirkan perubahan gagasan mereka; 6) menciptakan lingkungan yang kondusif; 7) dapat memberikan kemudahan kepada siswa dalam mempelajari konsep IPA; dan 8) melatih siswa berpikir kritis dan kreatif (Sujarwanto, 2016; Suprapti, 2018; Umbara, 2017). Beberapa penelitian yang relevan dengan penelitian ini seperti penelitian yang dilakukan oleh (Sujarwanto, 2016) menemukan bahwa proses pembelajaran dengan menerapkan model pembelajaran Konstruktivisme dapat meningkatkan aktivitas belajar siswa pada materi ciri-ciri mahluk hidup di kelas III. Kemudian penelitian yang dilakukan oleh (Primayana et al., 2019) menemukan bahwa terdapat perbedaan pada hasil belajar IPA siswa yang mengikuti pembelajaran model pembelajaran kontekstual berbasis lingkungan dengan siswa yang mengikuti pembelajaran konvensional. Penelitian lain juga menemukan bahwa model pembelajaran konstruktivisme cocok diterapkan dalam pembelajaran matematika teknik (Azman et al., 2020). 


\section{CONCLUSION}

Penggunaan model pembelajaran kontruktivisme berbasis lingkungan dapat mempengaruhi hasil belajar siswa dengan baik. Hasil belajar siswa meningkat setelah perlakuan tindakan.

\section{REFERENCES}

Azhari, B., \& Irfan, A. (2018). Model-Eliciting Activities Dalam Menganalisis Kreativitas Pemecahan Masalah Matematika Pada Mahasiswa Pendidikan Matematika Di Ptkin Aceh. Al-Khawarizmi: Jurnal Pendidikan Dan Pembelajaran Matematika, 2(1). https://doi.org/10.22373/jppm.v2i1.4495.

Azman, A., Jalinus, N., Ambiyar, A., \& Giatman, M. (2020). Model Pembelajaran Konstruktivisme dalam Pembelajaran Matematika Teknik. Jurnal Teknik, 14(1), 142147. https://doi.org/10.31849/teknik.v14i1.4218.

Dipayana, I. K. M., Gading, I. K., \& Japa, I. G. N. (2019). Pengaruh Pendekatan Pembelajaran Matematika Realistik Indonesia terhadap Hasil Belajar Matematika Ditinjau dari Minat Komputasi. Mimbar PGSD Universitas Pendidikan Ganesha, 7(3). https://ejournal.undiksha.ac.id/index.php/JJPGSD/article/view/19466/11529.

Harianti, F. (2018). Pengaruh Model Pembelajaran Guided Discovery Learning Terhadap Kemampuan Pemahaman Dan Hasil Belajar Siswa Materi Operasi Aljabar Kelas Vii Smp. MusT: Journal of Mathematics Education, Science and Technology, 3(1), 8291. https://doi.org/10.30651/must.v3i1.1611.

Hasanah, N., Holilulloh, H., \& Nurmaisa, Y. (2016). The Influence Of Teachers' Teaching Discipline Toward The Students' Learning Activity In Senior High School. Eduhumaniora, 5(2). https://doi.org/10.17509/eh.v5i2.2842.

Jannah, M. M., Supriadi, N., \& Suri, F. I. (2019). Efektivitas Model Pembelajaran Visualization Auditory Kinesthetic (Vak) Terhadap Pemahaman Konsep Matematis Berdasarkan Klasifikasi Self-Efficacy Sedang Dan Rendah. AKSIOMA: Jurnal Program Studi Pendidikan Matematika, 8(1), 215-224. https://doi.org/10.24127/ajpm.v8i1.1892.

Juniarti, N. K. R., Margunayasa, I. G., \& Kusmariyatni, N. (2020). Hubungan Antara Pola Asuh Orang Tua dan Konsep Diri dengan Kompetensi Pengetahuan Matematika $\begin{array}{lllll}\text { Siswa. Jurnal Ilmiah Sekolah } & \end{array}$ https://doi.org/10.23887/jisd.v4i1.24273.

Primayana, K. H., Lasmawan, W., \& Adnyana, P. B. (2019). Pengaruh Model Pembelajaran Kontekstual Berbasis Lingkungan Terhadap Hasil Belajar Ipa Ditinjau Dari Minat Outdoor Pada Siswa Kelas IV. Jurnal Pendidikan Dan Pembelajaran Ipa Indonesia, 9(2), 72-79.

Purwaningtyas, P., Dwiyogo, W. D., \& Hariyadi, I. (2017). Pengembangan modul elektronik mata pelajaran pendidikan jasmani, olahraga, dan kesehatan kelas XI berbasis online dengan program edmodo. Jurnal Pendidikan: Teori, 2(1), 121-129. http://journal.um.ac.id/index.php/jptpp/article/view/8471/4100.

Rivaldi, K. H. O., Putra, D. K. N. S., \& Putra, I. K. A. (2018). Pengaruh Model Pembelajaran Problem Based Learning Berbantuan Audio Visual Terhadap Penguasaan Kompetensi Pengetahuan IPA. Jurnal Ilmiah Sekolah Dasar, 2(2), 128. https://doi.org/10.23887/jisd.v2i2.15494.

Setyadi, D., \& Qohar, A. (2017). Pengembangan Media Pembelajaran Matematika Berbasis Web Pada Materi Barisan Dan Deret. Kreano, Jurnal Matematika Kreatif-Inovatif, 8(1), 1-7. https://doi.org/10.15294/kreano.v8i1.5964

Sudarma, I. K. (2018). Pengembangan Media Interaktif Matematika Untuk Siswa Kelas Vii 
Di Sln Negeri Singaraja. Jurnal Edutech Undiksha, 6(1), 89-98.

Sugiyono. (2016). Metode Penelitian Kualitatif, Kuantitatif, dan R\&D. Alfabeta.

Sujarwanto, S. (2016). Penerapan Model Pembelajaran Konstruktivisme Pada Materi CiriCiri Mahluk Hidup Di Kelas Iii a Sd Negeri Keputran. Mimbar Sekolah Dasar, 3(1), 69-80. https://doi.org/10.17509/mimbar-sd.v3i1.2357.

Suprapti, E. (2018). Penerapan Teori Belajar Konstruktivisme untuk Meningkatkan Hasil Belajar Mahasiswa pada Mata Kuliah Matematika Dasar. MAJAMATH: Jurnal Matematika Dan Pendidikan Matematika, 1(1), 24. https://doi.org/10.36815/majamath.v1i1.116.

Umbara, U. (2017). Implikasi Teori Belajar Konstruktivisme dalam Pembelajaran Matematika. Jumlahku Jurnal Matematika Ilmiah STKIP Muhammadiyah Kuningan, 3(1). http://jurnal.upmk.ac.id/index.php/jumlahku/article/view/348.

Wahyudin, W. (2018). Optimalisasi Peran Kepala Sekolah dalam Implementasi Kurikulum 2013. Jurnal Kependidikan, 6(2), 249-265. https://doi.org/10.24090/jk.v6i2.1932. 